\title{
A new European species of genus Eristalis Latreille, 1804 (Diptera: Syrphidae)
}

\author{
Ante Vujić, Snežana Radenković, Tore R. Nielsen \& Smiljka Šimić
}

Vujić, A., Radenković, S., Nielsen, T. R. \& Šimić, S. 2004: A new European species of genus Eristalis Latreille, 1804 (Diptera: Syrphidae). — Entomol. Fennica 15: 119-123.

Eristalis tecta sp. n. is described, based on material from the Macedonian Museum of Natural History (Skopje, Macedonia, former Republic of Yugoslavia). This species is closely related to E. interrupta (Poda, 1761). Diagnostic characters of the species, together with figures of the male terminalia, are given. A checklist of the Eristalis species known from the Balkan Peninsula is presented.

Ante Vujić, University of Novi Sad, Faculty of Science, Department of Biology and Ecology, Trg Dositeja Obradovića 2, 21000 Novi Sad, Yugoslavia; E-mail: antev@ib.ns.ac.yu

Snežana Radenković, University of Novi Sad, Faculty of Science, Department of Biology and Ecology, Trg Dositeja Obradovića 2, 21000 Novi Sad, Yugoslavia; E-mail:kalorin@ib.ns.ac.yu

Tore R. Nielsen, Sandvedhagen 8, NO-4318 Sandnes, Norway; E-mail: trnielsen@c2i.net

Smiljka Šimić, University of Novi Sad, Faculty of Science, Department of Biology and Ecology, Trg Dositeja Obradovića 2, 21000 Novi Sad, Yugoslavia; E-mail: simics@ib.ns.ac.yu

Received 6 February 2003, accepted 3 September 2003

\section{Introduction}

Genus Eristalis Latreille, 1804 is widely distributed over the Palaearctic, Nearctic and Oriental regions. Peck (1988) listed 46 Eristalis species occurring in the Palaearctic, and Telford (1970) listed 25 for the Nearctic region. The adults of many the species closely resemble bees (Apis) or bumble bees (Bombus, Psithyrus) in their colour patterns and pilosity. The larvae ("rat-tailed maggots") are saprophagous aquatic insects with a characteristic long and extensible posterior respiratory process.

Kanervo (1938) distinguished several groups of species based on the structure of male termi- nalia and other morphological characters. Holinka (1999) revised the Eristalis rupium species group for the Czech and Slovak Republics and gave a key to the central European species. However, neither Kanervo nor Holinka studied all the necessary type material, leaving many nomenclatural and taxonomic problems unresolved. The comprehensive revision of western Palaearctic Eristalis species carried out by Hippa et al. (2001) contained discussion on the identity of 20 species, their diagnostic characters and a key. These authors established new synonyms and designated various lectotypes and neotypes.

Until now, 11 Eristalis species have been recorded from the Balkan Peninsula (Šimić and 
Vujić 1990), and data on the hoverflies of Macedonia in particular have been presented by Glumac (1968).

A recent review of the syrphid collections in the Macedonian Museum of Natural History in Skopje, Macedonia, former Republic of Yugoslavia (FRY) resulted in a discovery of a distinct, so far undescribed species. This species is described here as Eristalis tecta Vujić, Radenković \& Nielsen, sp. n.

\section{Material and methods}

The type material is derived from two localities on Kožuf mountain (Golema poljana and Gevgeliska banja). Kožuf is a mountain in southern Macedonia, at the Greek border. It is located between the town of Gevgelija and Nidža mountain. Three biotopes (Matvejev \& Puncer 1989) are present on this mountain: Submediterranean, mostly broad-leaved woodlands, pastures and woodlands on rocky terrain of Oromediterranean mountains, and southern European, mostly deciduous, montane woodlands. Both study localities are situated in beech (Fagus) forest along streams and rivers.

Terminology follows Mc Alpine et al. (1981) and Speight (1987).

\section{Results}

Eristalis tecta Vujić, Radenković \& Nielsen sp. $\mathrm{n}$.

Type locality. Europe, Macedonia (FRY), Kožuf mountain, Golema poljana.

Type material. Holotype: male, Macedonia (FRY), Kožuf mountain, Golema poljana, 15.VI. 1956, leg. Cingovski. Paratype: male, Macedonia (FRY), Gevgeliska banja, 26.IV.1957, leg. Bogoevski. Both specimens are deposited in the collections of the Macedonian Museum of Natural History, Skopje, Macedonia (FRY).

Diagnosis. A medium-sized, short haired Eristalis species resembling E. interrupta (Poda, 1761). It has a bare arista, yellow facial ground colour except for the black median stripe, a dull mesonotum without stripes, wings unclouded, the wing completely covered in microtrichia and

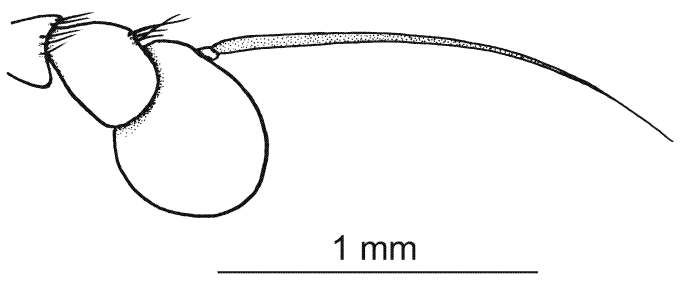

Fig. 1. The antenna of Eristalis tecta sp. n.

with a short pterostigma. Tergite $2-4$ with orange-yellow spots.

Description (male). Body length 10.4-12.5 $\mathrm{mm}$, wing length $8.5-8.7 \mathrm{~mm}$. Head: Antenna (Fig. 1) brown; first and second joint and arista reddish brown, third joint dark brown, 1.3 times longer than broad; arista more than 3 times longer than third antennal joint, bare (microscopic hairs visible only under high magnification). Face yellow except for the shining, black, median stripe that occupies $0.2-0.3$ of facial width, covered with yellow hairs, the yellow parts of the face with light yellow dusting. Frons dark medially with predominantly black hairs, yellow and yellow haired laterally, covered with dense dusting. Lunula brown. Vertex greyish black, dark grey dusted, with black and yellow hairs, ocellar triangle isosceles. Occiput black, dark grey dusted, yellow haired. Eyes with greyish-yellow pile; eyes touching for a distance which is 2.5 times longer than that between front and hind ocelli.

Thorax. Mesonotum dull black except for the light brown humeri and postalar calli; without longitudinal stripes, predominantly yellowhaired, but with black hairs intermingled in the posterior half. Pleurae greyish dusted; anepisternum, anepimeron and katepisternum covered with long yellow hairs. Scutellum yellow, translucent, mainly black-haired on the disc, yellowhaired on the margins. Wings hyaline, slightly yellowish, entirely covered with microtrichia. Pterostigma only slightly longer than deep. Calypters and halteres pale yellow. Legs brown except for the narrow yellow tips of the femora, the front-tibiae are yellow on basal 3/4, mid-tibia yellow on basal $3 / 4$ and hind-tibia yellow on basal 3/5 of their length. The mid-tarsi have the basitarsus and part of the second tarsomere yellow, and the ventral surface yellow on all tarsi. The hind-basitarsus seen is rather slender in pro- 
Fig. 2. Eristalis tecta sp. n., male genitalia. -a. Lateral view. -b. Ventral view, apical part of hypandrium. - c. Dorsal view, tergite $9 . \mathrm{bl}=$ basoventral lobe of surstylus, $\mathrm{dl}=$ dorsal lobe of surstylus, $\mathrm{s} 9=$ sternite 9 , al $=$ aedeagal lobe, $\mathrm{pr}=$ paramere. - d. Aedeagal lobe, lateral view. Scale bar $0.1 \mathrm{~mm}$.

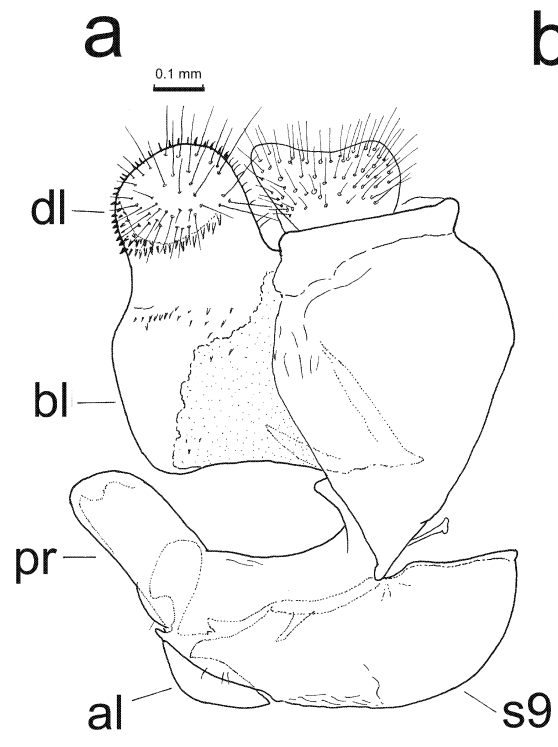

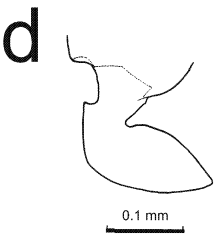

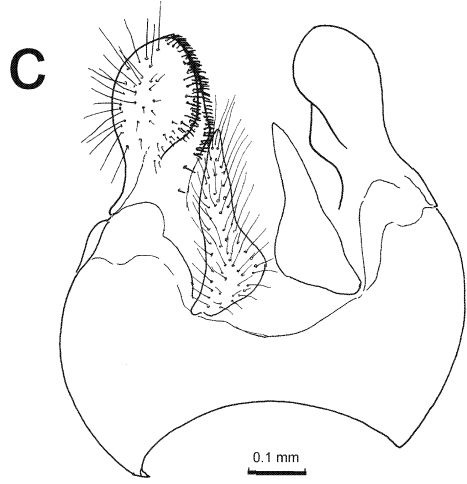

file, about $2 / 3$ of the thickness of the hind-tibia at apex. Legs mainly yellow-haired, except for black hairs postero-dorsally at the apical end of the front femora, a few black bristles below at the apical end of the mid-femora, black hairs posterodorsally at the apical end of the hind femora, and strong bristles postero-ventrally. Some black hairs present on dark areas of the front and mid tibiae, and strong black hairs arranged in a ventromedial line on the hind-tibiae.

Male genitalia (Fig. 2). In lateral view, very pronounced basoventral lobe of surstylus, rounded dorsal lobe of surstylus, broad sternite 9 , thick aedeagal lobe and a trapezoid paramere, with straight dorsal and ventral margins.

Abdomen (Fig. 3). Tergites black, except for

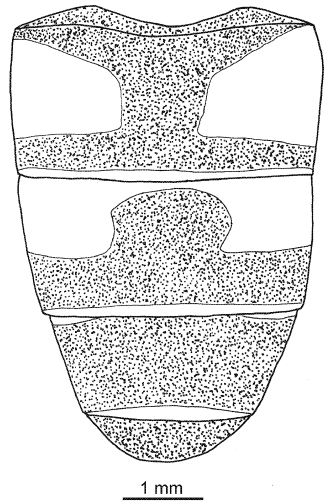

Fig. 3. Eristalis tecta sp. n. Male abdomen. orange-yellow, baso-lateral spots on tergites 2-4 (narrowly connected medially, towards the anterior margin of the tergite, on tergite 3 ) and yellow hind margins on tergites $2-4$. Tergites dull, but for a shining, transversal stripe just after the middle of each tergite, on tergites 2-4. The hair colour mainly follows the ground colour of the integument. Sternites slightly dusted, translucent orange-yellow, except for a dark brown area in the middle of sternites 1-2, a dark brown, wide stripe on the posterior $3 / 4$ of sternite 3 , and a predominantly dark brown sternite 4 . Hairs on the sternites long, pale yellowish except for some short black hairs on the hind margin of sternite 4 .

Female. Unknown.

Etymology. The name is derived from the Latin word tectus, perfect participle passive of tego, that has two meanings: firstly, hidden, put out of sight, secret (because it has been undiscovered for a very long time), and secondly, covered by something (here, wings are covered with dense microtrichia). Since Eristalis is feminine, this name has been used in the feminine form.

\section{Discussion}

Eristalis tecta sp. n. is distinguished from all other West Palaearctic Eristalis species by its 
combination of a bare arista and wholly microtrichose wings, as well as in its characteristic male genitalia (see Results and Fig. 2). As E. tecta resembles $E$. interrupta much, the following differences between these two species should be highlighted: arista bare (long-haired in interrupta), wings wholly micro-trichose (not bare as in other Eristalis species) and posterior half of mesonotum also with some black hairs (which are lacking in interrupta). Hind-basitarsus, seen in profile, is about $2 / 3$ the thickness of the tibia at its apex (of equal thickness in interrupta). Tibiae are more yellow than in interrupta: basal $3 / 4$ of $\mathrm{t} 1$ (about $1 / 2$ in interrupta); $3 / 4$ of $\mathrm{t} 2$ (2/3-3/4 in interrupta) and $3 / 5$ of $\mathrm{t} 3(2 / 5$ in interrupta).

The male genitalia, in lateral view, are with a broader dorsal lobe of surstylus (dl in Fig. 2) than in interrupta (see figure 16A in Hippa et al. [2001]), straight dorsal and ventral margins of paramere (pr in Fig. 2a), but uneven (or wavy) in interrupta (see figure 16A Hippa et al. [2001]). Aedeagal lobe, in ventral view, is shorter and less curved (al in Fig. 2b) than in interrupta (see figure 16B in Hippa et al. [2001]).

In the key of Violovitsh (1983), E. tecta sp. n. may key out as E. corymbus Viol., 1975 but differs from the latter in its wholly microtrichose wings. This character also separates it from E. transcaucasica Kuznetzov, 1994, described from Caucasus.

E. tecta can be included in the key of West Palaearctic species of Hippa et al. (2001) as follows:

A. Wing wholly microtrichose... E. tecta sp. n.

B. Wing hyaline...............

\section{Checklist of Eristalis species on the Balkan Peninsula}

\section{Eristalis alpina (Panzer, 1798)}

Glumac (1972), Šimić and Vujić (1990), Dirickx (1994)

\section{Eristalis arbustorum (Linnaeus, 1758)}

Glumac (1972), Šimić \& Vujić (1984, 1990, 1996), Kula (1985), Šimić (1987), Dirickx (1994), Vujić et al. (1998, 2000)
3. Eristalis interrupta (Poda, 1761)

nemorum auct. nec Linnaeus (1758)

As nemorum in Glumac (1972), Šimić (1987),

Šimić \& Vujić (1990, 1996) and Dirickx (1994)

4. Eristalis intricaria (Linnaeus, 1758)

Glumac (1972), Šimić \& Vujić (1990), Dirickx (1994)

\section{Eristalis jugorum Egger, 1858}

Glumac (1972), Šimić (1987), Dirickx (1994), Šimić \& Vujić (1996), Vujić et al. (1997)

\section{Eristalis lineata (Harris, 1776)}

horticola De Geer, 1776 auct.

As horticola in Glumac (1972), Šimić (1987), Šimić \& Vujić (1990, 1996), Dirickx (1994) and Vujić et al. (1998)

\section{Eristalis pertinax (Scopoli, 1763)}

Glumac (1972), Kula (1985), Šimić (1987), Šimić \& Vujić (1990, 1996), Dirickx (1994), Vujić et al. (2000)

\section{Eristalis picea (Fallén, 1817)}

Vujić et al. (1998)

\section{Eristalis rupium Fabricius, 1805}

Glumac (1972), Šimić \& Vujić (1990, 1996), Dirickx (1994), Vujić et al. (1997)

10. Eristalis similis (Fallén, 1817)

syn. pratorum Meigen, 1822

As pratorum in Glumac (1972), Kula (1985), Šimić (1987), Šimić \& Vujić (1990, 1996), Dirickx (1994) and Vujić et al. (1998, 2000)

\section{Eristalis tecta sp. n.}

\section{Eristalis tenax (Linnaeus, 1758)}

Glumac (1972), Kula (1985), Šimić (1987), Šimić \& Vujić (1990, 1996), Dirickx (1994), Vujić et al. $(1998,2000)$

Among Eristalis species, the only doubtful Balkan taxon remaining is E. nigritarsis Macquart, 1834, as published by Drensky (1934) for Bulgaria. The validity of this record requires confirmation.

Recently, E. nigritarsis was synonymized 
with Syrphus cryptarum Fabricius, 1794 by Hippa et al. (2001).

Acknowledgements. The authors are grateful to Mr. Vladimir Krpač for permitting us to study the collection in his care from the Macedonian Museum of Natural History, Skopje, FRY Macedonia. We are also grateful to the Ministry of Science, Technology and Development of Republic Serbia for their financial support (project number 1770). Dr. Sergey Yu. Kuznetzov, Zool. Inst., St. Petersburg, kindly informed us about characters of Eristalis corymbus Viol. and E. transcaucasica Kuzn. Our cordial thanks also to Dr. Martin C. D. Speight, Dublin, for checking the language of this paper.

\section{References}

Dirickx, H. 1994: Atlas des Dipteres syrphides de la region mediterraneenne. - Studiedocumenten van het Koninklijk Belgish Instituut voor Natuurwetenschappen 75: 1-317, Brussel.

Drensky, P. 1934: Die Fliegen der Familie Syrphidae (Diptera) in Bulgarien. - Mitt. Bulg. Ent. Ges. 8: 109-131.

Glumac, S. 1968: Sirfide (Syrphoidea, Diptera) u Makedoniji. - Godišnjak Filozofskog Fakulteta u Novom Sadu 11: 845-880.

Glumac, S. 1972: Catalogus Faunae Jugoslaviae, Syrphoidea. - Slovenska Akademija Znanosti in Umetnosti 3: 1-71.

Hippa, H., Nielsen, T.R. \& Steenis, J. v. 2001: The West Palaearctic species of the genus Eristalis Latreille (Diptera, Syrphidae). — Norw. J. Entomol. 48: 289 327.

Holinka, J. 1999: Occurence of Eristalis rupium-group species in Czech and Slovak Republics with complete key to Centraleuropean Eristalis species. - Dipterologica Bohemoslovaca 9: 53-56.

Kanervo, E. 1938: Zur systematik und Phylogenie der westpaläarktischen Eristalis-Arten (Dipt.) mit einer Revision derjenigen Finlands. - Annls Univ. Turkuensis (A) 6: 5-54.

Kula, E. 1985: A contribution to the knowledge of Syrphidae (Diptera) in Yugoslavia. - Acta Universitatis Agriculturae C 54: 203-223.

Kuznetzov, S. Y. 1994: Cryptoeristalis, a new subgenus of Eoseristalis Latreille (Diptera: Syrphidae), with a de- scription of a new species from Caucasus. Dipterological Research 5: 231-238.

Matvejev, S. D. \& Puncer, I. J. 1989: Karta bioma. Predeli Jugoslavije i njihova zaštita. — Prirodnjački Muzej Beograd, Posebna izdanja 36: 1-76.

McAlpine, J. F. 1981: Morphology and terminology adults. - In: McAlpine, J. F. et al. (eds.), Manual of Nearctic Diptera. Vol. 1: 9-63. Research Branch, Agriculture Canada, Monograph 27, Ottawa.

Peck, L.V. 1988: Syrphidae. — In: Soós, Á. \& Papp, L. (eds.), Catalogue of Palaearctic Diptera. Vol. 8 (Syrphidae - Conopidae): 11-230. Akadémia Kiadó, Budapest. 363 pp.

Speight, M. C. D. 1987: External morphology of adult Syrphidae (Diptera). - Tijdschrift voor Entomologie 130: 141-175.

Šimić, S. 1987: Syrphidae (Insecta: Diptera). Fauna of Durmitor Mauntain. Syrphidae (Insecta: Diptera). Fauna Durmitora, sv. 2. - CANU, Titograd. [In Serbian with English summary].

Šimić, S. \& Vujić, A. 1984: Composition of syrphid fauna (Diptera, Syrphidae) collected by Malaise trap. Zborn. Mat. Srp. za prir. nauke 66: 145-153. [In Serbian with English summary].

Šimić, S. \& Vujić, A. 1990: Vrste roda Eristalis Latreille, 1804 (Diptera: Syrphidae) iz zbirke Instituta za Biologiju u Novom Sadu. - Glasnik Prirodnjaćkog muzeja u Beogradu B 45: 115-126.

Šimić, S. \& Vujić, A. 1996: Hoverfly fauna (Diptera: Syrphidae) of the southern part of the mountain Stara Planina, Serbia. - Acta entomologica serbica, 1: 2130.

Telford, H.S. 1970: Eristalis (Diptera: Syrphidae) from America North of Mexico. - Ann. Ent. Soc. America 63: $1201-1210$.

Vujić, A., Milankov, V., Radović, D. \& Tanurdžić, M. 1997: Diversity of Hoverflies (Diptera: Syrphidae) in The National Park "Biogradska Gora" (Montenegro, Yugoslavia). - Univ. of Priština (Serbia), Nat. Sci Univ. misao (prir. nauke), Priština 3: 35-40.

Vujić, A., Šimić, S., Milankov, V., Radović, D., Radišić, P. \& Radnović, D. 1998: Fauna of Syrphidae (Insecta: Diptera) on Obedska bara. - Republićki zavod za zaštitu prirode. Beograd. Monograph. [In Serbian with English summary].

Vujić, A., Šimić, S. \& Radenković, S. 2000: New data of hoverflies (Diptera, Syrphidae) in Greece. Dipteron 3: 17-26.

Violovitsh, N.A. 1983: Sirfidi Sibiri (Diptera, Syrphidae). — Novosibirsk. 242 pp. [In Russian]. 